\title{
Efektivitas small sided games dan interval training terhadap peningkatan daya tahan aerobik pada pemain sepakbola U-17
}

\author{
Andi Tri Arianto *, Caly Setyawan \\ Program Studi Ilmu Keolahragaan, Program Pascasarjana, Universitas Negeri Yogyakarta. \\ Jalan Colombo No. 1, Karangmalang, Yogyakarta 55281, Indonesia. \\ * Corresponding Author. Email: andythres03@gmail.com \\ Received: 10 September 2019; Revised: 18 November 2019; Accepted: 22 December 2019
}

\begin{abstract}
Abstrak
Penelitian ini bertujuan untuk membandingkan pengaruh antara latihan small sided games (SSG) dan interval training (IT) terhadap daya tahan aerobik pemain sepakbola under-17. Sebanyak 24 pemain sepakbola U-17 yang dibagi menjadi 2 grup: grup SSG $(n=12)$ dan grup IT $(n=12)$ mengikuti program latihan selama 6 minggu. Instrumen penelitian yang digunakan adalah Yo-Yo Intermitten Recovery Test. ANAVA dua jalur digunakan untuk proses analisis data. Pemain dari kedua grup menunjukkan peningkatan yang sama pada daya tahan aerobik selama periodesasi latihan 6 minggu. Hasil ini menunjukkan bahwa SSG dan IT sama efektif dalam meningkatkan daya tahan aerobik pada pemain sepakbola U-17 $(p<0.05)$.
\end{abstract}

Kata Kunci: daya tahan aerobik, interval training, small sided games

\section{Effect of small sided games and interval training on aerobic endurance of $U-17$ soccer players}

\begin{abstract}
This study aims to compare the effect of small sided games and interval training on the aerobic endurance of U-17 soccer players. 24 soccer players under 17 attended a 6-week training program divided into 2 groups: SSG group $(n=12)$ and IT group $(n=12)$. The research instrument used was Yo-Yo Intermitten Recovery Test. Two-way ANOVA is used for data analysis. Players from both groups showed a similar increase in aerobic endurance during the 6-week training period. These results indicate that SSG and IT are equally effective in developing the aerobic endurance in U-17 soccer players ( $p<0.05)$.
\end{abstract}

Keywords: aerobic endurance, interval training, small sided games

How to Cite: Arianto, A., \& Setyawan, C. (2019). Efektivitas small sided games dan interval training terhadap peningkatan daya tahan aerobik pada pemain sepakbola U-17. Jurnal Keolahragaan, 7(2), 182-191. doi:https://doi.org/10.21831/jk.v7i2.27039

https://doi.org/10.21831/jk.v7i2.27039

\section{PENDAHULUAN}

Ekspansi ilmu pengetahuan olahraga, khususnya strenght training dan conditioning pada sepakbola meningkat secara luar biasa dalam beberapa tahun terakhir. Kini, selain keterampilan teknis dan taktis, pemain sepakbola harus mengembangkan dan mempertahankan tingkat kebugaran fisik yang tinggi untuk menjadi sukses (Christopher et al., 2016). Kebutuhan akan metode latihan yang sesuai dengan karakteristik permainan sepakbola telah mendorong studi ilmiah untuk mengevaluasi metode latihan daya tahan aerobik yang tepat untuk pemain sepakbola (Katis \& Kellis, 2009; Sarmento et al., 2018). Penelitian-penelitian tersebut menunjukkan bah- wa daya tahan aerobik menjadi faktor penting dalam sepakbola.

Beberapa metode latihan yang digunakan untuk meningkatkan kebugaran energi dalam hal kapasitas aerobik, di antaranya, adalah latihan interval training, continuous training, circuit training, dan fartlek. Selama beberapa dekade terakhir, interval training telah menjadi salah satu metode pengkondisian fisik yang paling umum digunakan pada olahraga yang membutuhkan daya tahan (Pandey \& Verma, 2016). Studi Deol dan Singh (2013) menunjukkan metode continuous running dan metode interval training secara signifikan membantu meningkatkan kemampuan daya tahan pemain sepakbola dengan metode interval training secara signifikan lebih 
baik dibandingkan dengan metode continuous running. Meskipun interval training dinilai dapat meningkatkan daya tahan atlet, namun metode ini membutuhkan manipulasi dalam hal jarak, durasi, pengulangan, waktu istirahat, dan tindakan saat istirahat agar sesuai dengan cabang olahraga tertentu (Turner \& Stewart, 2014).

Dalam permainan sepakbola, daya tahan aerobik, kecepatan, kelincahan, kekuatan dan daya ledak dinilai sebagai indikator penentu performa yang superior (Casamichana et al., 2015; Joo et al., 2016; Lacome et al., 2018). Namun demikian, perlu dicatat bahwa karakteristik fisiologis dan fisik di antara berbagai posisi dalam permainan sepakbola bervariasi (Halouani et al., 2017). Tuntutan upaya meningkatkan daya tahan aerobik yang dilakukan melalui bentuk-bentuk latihan yang sesuai dengan karakteristik permainan sepakbola mendorong berkembangnya metode latihan small sided games. Small sided games dilakukan di area yang lebih kecil, dengan aturan yang dimodifikasi dan dengan pemain yang lebih sedikit daripada permainan sepakbola sesungguhnya (Badin et al., 2016; Sarmento et al., 2018).

Dalam beberapa tahun terakhir, banyak perhatian difokuskan pada penggunaan small sided games sebagai alat conditioning di sepakbola elit karena karakteristik situasi yang sama dengan permainan (Clemente et al., 2014b; Dellal et al., 2012; Köklü et al., 2013). Sebelumnya, Impellizzeri et al. (2006) menemukan small sided games secara signifikan meningkatkan kebugaran aerobik ke tingkat yang sama dengan sesi kebugaran fisik secara tradisional, menyimpulkan bahwa keduanya sama-sama efektif dalam populasi pemuda sub elit. Temuan ini telah dikonfirmasi dalam populasi elit (Clemente et al., 2014b; Dellal et al., 2012; Hill-Haas et al., 2009). Small sided games dapat memberikan kesempatan untuk mengembangkan elemen teknis dan taktis bersamaan dengan kapasitas kebugaran tertentu seperti daya tahan (aerobik dan anaerobik), kekuatan dan kelincahan (Halouani et al., 2017; Hill-Haas et al., 2011; Sangnier et al., 2019).

Beberapa penelitian di atas menunjukkan bahwa small sided games merupakan suatu bentuk latihan yang relevan dengan situasi dalam permainan. Bentuk latihan yang dimodifikasi dari jumlah pemain dan ukuran lapangan (dari 11v11 - 3v3) meningkatkan banyak aksi (keterampilan teknik) (Serra-Olivares et al., 2015). Selain itu para pemain dituntut untuk selalu aktif dalam area yang lebih sempit sehingga membuat pemain harus lebih cepat mengambil keputusan dan mengeksekusinya (Mara et al., 2016). Hal ini tentunya sesuai dengan kebutuhan mengajarkan prinsip bermain kepada pemain usia 14-17 tahun yang sedang berada pada fase pengembangan (Danurwindo et al., 2017, p. 60).

Small sided games menawarkan alternatif yang menarik sebagai bentuk conditioning dalam sepakbola selain metode interval training yang telah umum digunakan. Keduanya dinilai telah terbukti secara signifikan meningkatkan daya tahan aerobik pemain sepakbola elit, sedangkan hasil pada pemain remaja masih sedikit diketahui. Oleh karena itu, perlu dilakukan penelitian yang bertujuan untuk membandingkan pengaruh latihan small sided games dan interval training terhadap peningkatan daya tahan aerobik pemain sepakbola remaja, dalam hal ini pemain berusia di bawah 17 tahun.

\section{METODE}

\section{Prosedur Eksperimen}

Untuk menyelidiki efektivitas small sided games, digunakan 3 bentuk latihan $(4 \mathrm{v} 4,5 \mathrm{v} 5$, dan 7 v 7) dengan dimensi lapangan yang disesuaikan dengan metode latihan aerobik (Clemente et al., 2014a) (Tabel 1). Sedangkan untuk menyelidiki efektivitas interval training menggunakan dimensi lapangan $30 \times 13 \mathrm{~m}$ dengan metode extensive interval method (Bompa $\&$ Haff, 2009) (Tabel 3). Sebelum melakukan sesi SSG dan IT para pemain melakukan pemanasan selama 15 menit.

Dua puluh empat pemain Akademi FC UNY U-17 yang berkompetisi di tingkat regional (Rata-rata berumur $15.5 \pm 0.8$ tahun) berpartisipasi dalam penelitian ini. Pengambilan sampel pada penelitian ini menggunakan cara random sampling. Sampel peserta termasuk semua posisi bermain, termasuk penjaga gawang. Partisipan berlatih enam jam per minggu atau setara dengan tiga kali latihan per minggu. Selama studi, partisipan diinstruksikan untuk mempertahankan asupan makanan dan minuman harian mereka, dan tidak ada intervensi diet yang dilakukan. Para pemain diminta untuk mengkonsumsi makanan biasa mereka setidaknya tiga jam sebelum waktu pengujian yang dijadwalkan. Penelitian dilaksanakan selama 6 minggu pada fase persiapan umum tim dengan frekuensi $3 x$ latihan per minggu.

\section{Yo-Yo Intermitten Recovery Test Level 2}

Partisipan dibagi dalam dua grup, yaitu grup small sided games (SSG) dan grup interval 


\section{Jurnal Keolahragaan 7 (2), 2019 - 184}

Andi Tri Arianto, Caly Setyawan

training (IT). Sebelum dan setelah periode intervensi, Yo-Yo Intermittent Recovery Test Level 2 (YYIR2) digunakan untuk mengukur daya tahan aerobik pemain. Tes dilakukan di sore hari. Yoyo Intermittent Recovery Test dibuat untuk mengevaluasi kemampuan pengulangan lari dengan intensitas tinggi dalam jarak pendek 20 meter. Lari ini dimulai dari level lima sampai dengan selesai dengan peningkatan kecepatan pada setiap level. Waktu 10 detik diberikan sebagai istirahat aktif diantara lari 20 meter (Thomas et al., 2006).

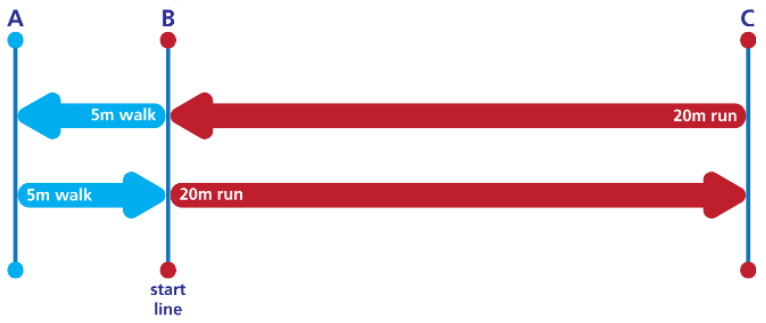

Gambar 1. YYIR2

Tes Yo-Yo IR2 (Gambar 1) dilakukan sesuai metode Krustrup et al. (2003). Audio untuk Yo-Yo IR2 diputar menggunakan CD player (Panasonic ${ }^{\mathrm{TM}}$ ). Tes dihentikan ketika peserta berhenti secara sukarela atau gagal dua kali untuk mencapai garis finish tepat waktu. Total jarak yang ditempuh selama Yo-Yo IR2 dicacat sebagai hasil tes yang kemudian dikonversikan menjadi kapasitas aerobik maksimal $\left(\mathrm{VO}_{2} \mathrm{Max}\right)$.

\section{Program Latihan SSG}

Penyusunan program latihan SSG mengacu pada rekomendasi Sarmento et al. (2018) sebagaimana dapat dilihat pada tabel 1. Penelitian ini menggunakan prinsip whole - part - whole dengan menggunakan SSG 7 v 7, 5 v 5, dan 4 v 4. Prosedur jumlah pemain, jumlah set latihan, durasi permainan, ukuran lapangan dan durasi istirahat dapat dilihat pada Tabel 2.

\section{Program IT}

Program IT disusun berdasarkan hasil tes awal partisipan. Penentuan intensitas menggunakan RM (Repetisi Maximum). Metode IT yang digunakan dalam penelitian ini adalah extensive interval method (Tabel 3). Partisipan melakukan lari sesuai kecepatan masing-masing pada jarak 30 meter dan melakukan istirahat sesuai dengan waktu pada jarak 13 meter (Gambar 2).

Tabel 1. Metodologi Pengembangan SSG

\begin{tabular}{clccc}
\hline \multirow{2}{*}{ Shape of game } & Lactate threshold & VंO2max & Anaerobic \\
\cline { 3 - 5 } Intensity & \%Hrmax & $80-90$ & $90-95$ & $>85$ \\
& RPE & Quite hard & Stressful & Maximal \\
\multirow{5}{*}{ Duration } & Blood lactate (mmol/L) & $3-6$ & $6-12$ & $>10$ \\
& Total work (min) & $30-60$ & $12-35$ & Apr-16 \\
& Repetitions & $1-4$ & $4-8$ & $2-4$ sets of 4-8 \\
& Repetitions duration (min) & $30-60$ & $3-6$ & 20 s to 3 min \\
& Recovery & $<1$ min & Ratio: $0.5: 1$ & Ratio: $1: 4$ \\
\hline
\end{tabular}

Tabel 2. Prosedur Pelaksanaan Latihan SSG

\begin{tabular}{|c|c|c|c|c|c|}
\hline Week & SSG & Set & Durasi & Grid & Rest \\
\hline 1 & 7 v 7 & 3 & 8 mins & $40 \times 60 \mathrm{~m}$ & $3 \mathrm{mins}$ \\
\hline 2 & 5 v 5 & 6 & 4 mins & $25 \times 35 \mathrm{~m}$ & $2 \mathrm{mins}$ \\
\hline 3 & $4 \mathrm{v} 4$ & 8 & 3 mins & $20 \times 30 \mathrm{~m}$ & $1 \mathrm{~min}$ \\
\hline 4 & 5 v 5 & 6 & 4 mins & $25 \times 35 \mathrm{~m}$ & $2 \mathrm{mins}$ \\
\hline 5 & 7 v7 & 3 & 8 mins & $40 \times 60 \mathrm{~m}$ & $3 \mathrm{mins}$ \\
\hline 6 & $11 \mathrm{v} 11$ & 1 & 24 mins & $60 \times 90 \mathrm{~m}$ & - \\
\hline
\end{tabular}

Tabel 3. Interval Training

\begin{tabular}{cccccc}
\hline Week & Intens & Reps & Dist & Rest & Time \\
\hline 1 & $60 \%$ & 5 & $688 \mathrm{~m}$ & $120 \mathrm{~s}$ & $30 \mathrm{mins}$ \\
2 & $70 \%$ & 5 & $602 \mathrm{~m}$ & $120 \mathrm{~s}$ & $25 \mathrm{mins}$ \\
3 & $80 \%$ & 4 & $688 \mathrm{~m}$ & $120 \mathrm{~s}$ & $23 \mathrm{mins}$ \\
4 & $90 \%$ & 4 & $602 \mathrm{~m}$ & $120 \mathrm{~s}$ & $21 \mathrm{mins}$ \\
5 & $80 \%$ & 4 & $688 \mathrm{~m}$ & $120 \mathrm{~s}$ & $23 \mathrm{mins}$ \\
6 & $70 \%$ & 5 & $602 \mathrm{~m}$ & $120 \mathrm{~s}$ & $25 \mathrm{mins}$ \\
\hline
\end{tabular}




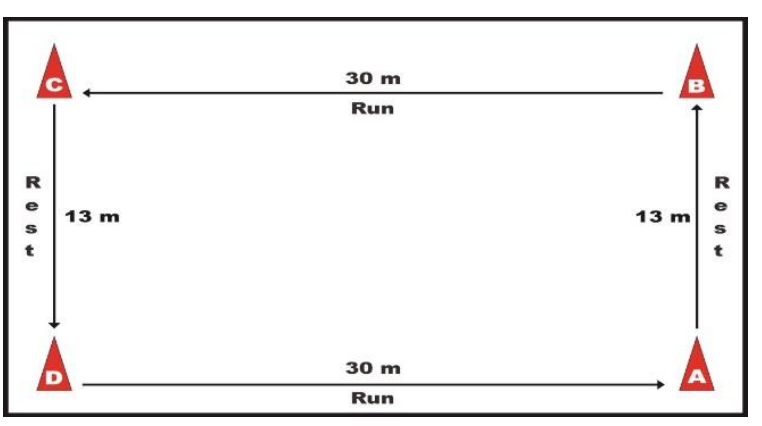

Gambar 2. Program Interval Training

Analisis Data

Analisis statistik dilakukan dengan software SPSS (versi 16.0; SPSS, Inc., Chicago, IL, USA). Data dinyatakan sebagai mean \pm standar deviasi. Tes Kolmogorov-Smirnov pertama kali diterapkan untuk mengonfirmasi normalitas distribusi data dan uji Levene diterapkan untuk menilai homogenitas varians. Karena data terdistribusi normal, variabel dependen (Small Sided Games dan Interval Training) dianalisis menggunakan analisis two-way ANAVA. Tingkat signifikansi didefinisikan sebagai $\mathrm{p}<0.05$.

\section{HASIL DAN PEMBAHASAN}

Grup IT menunjukkan peningkatan 7,88\% $(p=0.02)$. Grup SSG menunjukkan peningkatan sebesar 5,88\% ( $p=0.03)$. Hasil tersebut (Tabel 4) menunjukkan bahwa grup SSG dan grup IT mengalami peningkatan kapasitas daya tahan aerobik.

Tabel 4. Deskriptif Statistik $\mathrm{VO}_{2} \mathrm{Max}$

\begin{tabular}{cccc}
\hline \multirow{2}{*}{ Metode } & \multicolumn{2}{c}{ Rata-rata } & \multirow{2}{*}{ Peningkatan } \\
\cline { 2 - 3 } & Pretest & Posttest & \\
\hline IT & 50.65 & 54.64 & $7.88 \%$ \\
SSG & 50.83 & 53.82 & $5.88 \%$ \\
\hline
\end{tabular}

\section{Pengaruh SSG terhadap Peningkatan Daya} Tahan Aerobik

Hasil penelitian menunjukkan SSG meningkatkan daya tahan aerobik sebesar 5,88\% ( $p$ $=0.03$ ). Hasil ini dapat dikaitkan dengan hasil penelitian (Italo \& Cofano, 2017) yang menyebutkan bahwa SSG efektif digunakan sebagai alat untuk latihan aerobik dimana latihan SSG 3vs3, 4vs4, dan 5vs5 menghasilkan respons jantung yang mendekati 90\% dari DJM sementara format dengan jumlah pemain yang lebih besar menghasilkan peningkatan jumlah keterampilan teknis khusus dalam sepakbola.

SSG adalah bentuk latihan yang paling banyak digunakan oleh pelatih sepakbola saat ini. Small sided games digunakan untuk mengembangkan kemampuan teknis dan taktis, model latihan ini sekarang dipakai oleh banyak tim amatir dan profesional sebagai alat yang efektif untuk program latihan aerobik (Clemente et al., 2014b; Italo \& Cofano, 2017; Los Arcos et al., 2015; Reilly \& Gilbourne, 2003; Serra-Olivares et al., 2015). Hoff et al. (2002) menemukan bahwa small sided games $5 \mathrm{v} 5$ di lapangan berukuran 50 x 40 m menghasilkan respons detak jantung dalam kisaran intensitas yang sebelumnya ditunjukkan oleh Helgerud et al. (2001) efektif untuk meningkatkan kebugaran aerobik dan kinerja sepakbola (latihan interval 90-95\% dari denyut jantung maksimal).

Penelitian selanjutnya telah menunjukkan bahwa 12 minggu latihan interval aerobik yang dilakukan dengan menggunakan small sided games efektif dalam meningkatkan daya tahan aerobik dan kinerja fisik dalam pertandingan (Beato et al., 2014; Impellizzeri et al., 2006). Studi Dellal (2012) menunjukkan bahwa periode 6 minggu sesi latihan termasuk small sided games dapat meningkatkan kapasitas aerobik, komponen anaerob spesifik, dan kemampuan untuk mengulangi aksi intensitas tinggi dengan perubahan arah oleh pemain sepakbola amatir dalam proporsi yang sama dengan sesi latihan intermiten intensitas tinggi. Penelitian ini semakin menegaskan bahwa small sided games efektif dalam meningkatkan daya tahan aerobik pemain sepakbola under-17.

\section{Pengaruh Interval Training terhadap Peningkatan Daya Tahan Aerobik Pemain Sepakbola Under-17}

Hasil penelitian menunjukkan IT meningkatkan daya tahan aerobik sebesar 7,88\% ( $p=$ 0.02 ). Hasil ini dapat dikaitkan dengan hasil penelitian Turnes et al. (2016) yang menunjukkan bahwa IT secara signifikan meningkatkan daya tahan aerobik $(p<0.01)$.

Hal ini terjadi karena dalam program latihan interval yang digunakan sesuai dengan rekomendasi dari Bompa dan Haff (2009, p. 143) yaitu extensive method yang termasuk kedalam aerobic interval training. Metode latihan interval ini dominan menggunakan sistem energi aerobik sehingga sesuai dengan tujuan dalam penelitian ini. Deol dan Singh (2013) menunjukkan bahwa latihan interval secara signifikan meningkatkan kapasitas aerobik. Hasil ini menunjukkan metode ini secara positif meningkatkan kemampuan daya tahan aerobik setelah dilakukan tes awal dan tes akhir. Interval training adalah metode yang paling serbaguna untuk meningkatkan daya tahan. Macpherson dan Weston (2015) menyebutkan 
bahwa IT meningkatkan hasil test YYIRL 1 (8\%; $\pm 16 \%$ ) pada pemain sepakbola dewasa, sehingga IT merupakan metode latihan terukur untuk meningkatkan kebugaran aerobik. Penelitian ini semakin menegaskan bahwa interval training efektif dalam meningkatkan daya tahan aerobik pemain sepakbola under-17.

\section{Perbedaan Pengaruh Antara Latihan Small Sided Games dan Interval Training tehadap Peningkatan Daya Tahan Aerobik Pemain Sepakbola Under-17}

Tujuan utama dari penelitian ini adalah untuk membandingkan efektivitas small sided games dan interval training pada daya tahan aerobik pemain sepakbola U-17. Karena kedua metode pelatihan cenderung mendapatkan respons kardiorespirasi yang tinggi (Dellal et al., 2012; Pattyn et al., 2017; Sarmento et al., 2018; Vilar et al., 2014), kami berharap bahwa kedua program memiliki dampak yang serupa dalam meningkatkan daya tahan aerobik pemain sepakbola U-17. Hal ini dapat dipengaruhi oleh beberapa faktor menurut Bompa dan Haff (2009, p. 289) yaitu aerobic power, lactate threshold, dan pergerakan yang efektif. Berdasarkan hasil analisis data menggunakan two-way ANOVA ditemukan bahwa tidak ada perbedaan pengaruh yang signifikan antara small sided games dan interval training dalam peningkatan daya tahan aerobik pemain sepakbola U-17 ( $<$ 0.05). Kedua program latihan tersebut sama-sama efektif dalam meningkatkan daya tahan aerobik pemain sepakbola under- 17 .

Hal ini disebabkan karena small sided games dan interval training mempunyai karakteristik yang hampir sama yaitu dominan pada penggu naan sistem energi aerobik. Hal ini sesuai dengan rekomendasi hasil penelitian yang dilakukan oleh Helgerud et al. (2001) bahwa untuk meningkatkan daya tahan aerobik pada pemain sepakbola dengan cara menambah jarak tempuh latihan (distance covered), meningkatkan intensitas latihan, dan meningkatkan jumlah sprint serta keterlibatan dengan bola selama latihan. Pendapat tersebut didukung oleh temuan terbaru oleh Joo et al. (2016) dimana SSG 8 vs 8 secara signifikan meningkatkan jumlah sprint dan distance covered pada area $75 \times 47 \mathrm{~m}$. Penelitian ini menunjukkan bahwa tuntutan fisik pada SSG 8 vs 8 lebih tinggi daripada permainan 11 vs 11 dengan ukuran lapangan normal.

Sedangkan Deol dan Singh (2013) menunjukkan bahwa interval training secara signifikan meningkatkan kapasitas aerobik. Pattyn et al.
(2017) menjelaskan bahwa aerobic interval training dan continuous training meningkatan kapasitas pengambilan oksigen dalam tubuh sehingga secara otomatis juga meningkatan daya tahan aerobik secara signifikan dengan program latihan selama 6 minggu. Interval training adalah metode yang paling serbaguna untuk meningkatkan daya tahan. Interval training dilakukan dengan intensitas lebih tinggi dengan waktu istirahat yang lengkap. Penelitian sebelumnya telah menunjukkan bahwa small sided games dan interval training (generic running, continous training, dan high intensity interval training) efektif dalam meningkatkan daya tahan aerobik pada pemain sepakbola profesional.

Foster et al. (2015) mengungkapkan bahwa program latihan interval dapat disesuaikan untuk hampir setiap populasi dan dapat dilakukan di mana saja kapan saja. Bergantung pada kemampuan individu, pelatih dapat memanipulasi intensitas dan durasi interval, modalitas latihan, set dan pengulangan, serta intensitas dan durasi pemulihan antara set. Secara umum, durasi interval adalah variabel utama yang dimanipulasi. Intensitas yang relatif tinggi dipasangkan dengan interval pemulihan pendek dianggap sangat menuntut. Sebaliknya, intensitas rendah dipasangkan dengan interval pemulihan panjang.

Hal tersebut diperkuat oleh penelitian Pandey \& Verma (2016) yang menjelaskan bahwa: Interval method is perhaps the most versatile method for improving endurance of various types. In interval method, the exercise is done at relatively higher intensity with intervals of incomplete recovery. Interval method is based on the following principle: work should be done with sufficient speed and duration so that the heart rate goes up to 180 beats/ min".

Kedua latihan ini menekankan pada komponen biomotor yaitu kecepatan dan daya tahan. Ada beberapa penelitian yang telah meneliti penggunaan SSG sebagai stimulus conditioning dibandingkan dengan bentuk latihan kebugaran tradisional. Dalam studi pelatihan pertama yang dikendalikan untuk membandingkan SSG dan pelatihan generik, Reilly \& White (2004) merekrut 18 pemain sepakbola profesional muda dari klub sepakbola Premier League. Menggunakan parallel matched-group design, pemain dibagi menjadi grup SSG dan grup latihan interval aerobik (ITG). Pemain menyelesaikan latihan dua kali per minggu, sebagai bagian dari latihan normal mereka, selama periode 6 minggu selama musim kompetisi. SSG melibatkan 5 vs 5, dimainkan dalam interval $6 \times 4$ menit, diselingi 
dengan pemulihan aktif 3 menit pada $50-60 \%$ DJM. Durasi interval disesuaikan dengan SSG, dengan intensitas target 85-90\% DJM (pemulihan aktif 3 menit pada 50-60\% DJM). Semua ukuran kinerja fisiologis, termasuk counter movement jumps, sprint 10-30meter, anaerobic shuttle test 6-30 detik, the agility T-test dan the multi-stage fitness test, menunjukkan perubahan yang serupa selama penelitian. Berdasarkan hasil ini, penulis menyimpulkan bahwa SSG dan latihan interval sama-sama efektif untuk mempertahankan kebugaran aerobik dan anaerob musiman pada pemain sepakbola elit. Akan tetapi respon denyut jantung untuk setiap jenis latihan tidak dilaporkan, sehingga sulit untuk menentukan apakah kedua kelompok menerima beban latihan internal yang sama selama periode penelitian. Keterbatasan lebih lanjut dari penelitian ini adalah bahwa ada sedikit detail periodisasi dan program latihan SSG. Misalnya, format permainan dibatasi hingga 5 vs 5 untuk semua sesi, dan tidak ada detail yang berkaitan dengan area lapangan, aturan atau dorongan pelatih yang diberikan.

Dalam studi pelatihan komprehensif yang membandingkan SSG dengan pelatihan interval generik, Impellizzeri et al. (2006) menggunakan desain penelitian parallel matched-group, di mana 29 pemain sepak bola muda dari dua tim junior klub sepakbola profesional Italia dibagi secara acak ke SSG atau IT. Intervensi latihan 12 minggu mencakup lebih dari 4 minggu pramusim dan 8 minggu musim kompetisi di mana para pemain menyelesaikan dua sesi per minggu yang dirancang untuk meningkatkan daya tahan aerobik. Latihan interval terdiri dari program tetap dari upaya $4 \times 4$ menit dengan intensitas target 90-95\% dari DJM, diselingi dengan 3 menit pemulihan aktif pada 60-70\% DJM. Latihan SSG melibatkan campuran SSG, termasuk 3 vs 3, 4 vs 4 dan 5 vs 5 . Durasi dan intensitas latihan disesuaikan antar kelompok. Hasil menunjukkan tidak ada perbedaan dalam intensitas latihan ratarata (\% HRmax) atau beban latihan mingguan (sesi RPE) antar kelompok, dengan pengecualian waktu yang dihabiskan > 95\% HRmax, di mana kelompok SSG menghabiskan 30 detik per sesi lebih lama dalam zona ini. Hasil tes kebugaran mengungkapkan peningkatan yang serupa untuk kelompok ITG dan SSG untuk konsumsi oksigen puncak (masing-masing 8\% dan 7\%), ambang batas laktat (masing-masing 13\% dan 11\%) dan running economy (3\% untuk kedua kelompok) selama 12 minggu latihan. Khususnya, peningkatan konsumsi oksigen puncak untuk IT dan SSG untuk fase musim studi juga sangat mirip dengan studi sebelumnya dari O'Reilly et al. (2004) $(0,8 \%$ dan $0,7 \%$, dan masing-masing $0,3 \%$ dan $0,2 \%)$.

Impellizzeri et al. (2006) juga meneliti pengaruh strategi pelatihan generik dan spesifik pada kinerja fisik selama pertandingan. Hasil menunjukkan peningkatan yang tidak signifikan (hanya fase pelatihan pra-musim) dalam aktivitas intensitas rendah (maju, mundur dan menyamping), aktivitas intensitas tinggi (berlari dan berlari cepat) dan total jarak yang ditempuh untuk kelompok IT dan SSG mengikuti periode pelatihan 12 minggu. Namun, ketika ukuran kinerja pertandingan untuk fase musim pelatihan dianalisis, besarnya peningkatan (untuk kedua kelompok) dalam aktivitas intensitas rendah dan tinggi jauh lebih kecil.

Dellal et al. (2012) menjelaskan bahwa latihan SSG selama periode 6 minggu meningkatkan kapasitas aerobik, komponen anaerobik spesifik, dan kemampuan merubah arah dengan intensitas tinggi secara berulang-ulang pada pemain sepakbola amatir dengan proporsi latihan yang sama pada sesi latihan IT. Intervensi SSG dan IT sama-sama efektif dalam meningkatkan daya tahan arobik pemain sepakbola. Penelitian selanjutnya membandingkan pengaruh SSG dan IT terhadap kebugaran aerobik pada pemain elit dengan periode latihan 6 minggu menunjukkan peningkatan aktifitas kardiovaskular yang hampir mirip pada kedua kelompok latihan tersebut (Los Arcos et al., 2015).

Penelitian sebelumnya membandingkan pelatihan SSG dengan interval telah menunjukkan desain penelitian yang baik dan validitas internal yang tinggi. Namun di lapangan, ada aspek-aspek tertentu dari studi ini yang jarang terjadi. Misalnya, praktis sulit untuk menerapkan program latihan interval yang terukur dan tidak memiliki progressive overload saat melatih pemain sepakbola elit. Selain itu dalam praktiknya, manipulasi SSG secara sistematis untuk tujuan pengembangan fisik menjadi masalah, karena tujuan latihan teknis/taktis dari pelatih tidak selalu berkaitan dengan kebutuhan atau prioritas pengembangan fisiologis. Oleh karena itu, untuk memeriksa masalah ini, (Hill-Haas et al., 2009) menilai keefektifan program SSG yang dipimpin pelatih dan program latihan kebugaran generik campuran metode progresif pada 25 pemain sepakbola muda elit. Menggunakan desain penelitian parallel matched-group, para pemain dialokasikan secara acak baik untuk kelompok latihan SSG atau campuran generik selama periode pelatihan pra-musim 7 minggu. Berbeda 
dengan penelitian sebelumnya, penelitian ini menerapkan program latihan campuran-generik (terutama terdiri dari latihan kekuatan aerobik dan HIIT yang berkepanjangan), dan program latihan SSG, yang menggabungkan berbagai format permainan (yaitu 2 vs 2 hingga 7 vs 7). Meskipun manipulasi variabel latihan SSG (seperti area dan peraturan) kurang sistematis daripada studi sebelumnya, perbedaan utama adalah perencanaan dan implementasi program latihan SSG oleh pelatih berpengalaman, yang meningkatkan validitas eksternal penelitian. Temuan utama dari penelitian ini adalah bahwa latihan SSG yang dipilih oleh pelatih dan pelatihan campuran-generik (terdiri dari durasi pendek, interval intensitas tinggi <90 detik) secara signifikan efektif dalam meningkatkan kinerja pemulihan yo-yo intermiten (level 1), tetapi tidak pada $\mathrm{VO}_{2}$ Max. Tidak ada perubahan antar kelompok dalam ukuran kinerja lainnya.

Secara umum hasil penelitian ini menunjukkan bahwa SSG memberikan perubahan yang serupa dalam daya tahan aerobik dan mengukur kinerja pertandingan, dengan sebagian besar perubahan dalam kebugaran/kinerja fisik diamati selama latihan pra-musim. Studi juga menunjukkan bahwa penggunaan model latihan ini secara lebih efektif masih dimungkinkan. Ini dapat dicapai melalui manipulasi sistematis variabel pelatihan. Namun, jelas bahwa pemilihan format SSG dan regimen pelatihan yang cermat diperlukan untuk mengoptimalkan kebugaran dan pencapaian kinerja. Bukti menunjukkan bahwa latihan SSG dan latihan interval cocok untuk meningkatkan kebugaran dan kinerja pemain sepakbola. Sangat mungkin bahwa pendekatan metode campuran cocok untuk pelatihan sepakbola. Namun pemilihan ini harus didasarkan pada kebutuhan teknis, taktis dan kinerja para pemain. Hasil penelitian ini menunjukkan bahwa tidak ada perbedaan pengaruh yang signifikan antara small sided games dan interval training terhadap peningkatan daya tahan aerobik pemain sepakbola U-17.

\section{Aplikasi Praktis}

Studi ini menunjukkan bahwa periode latihan SSG selama 6 minggu dapat meningkatkan daya tahan aerobik secara signifikan pada pemain sepakbola U-17 dalam proporsi yang sama dengan program latihan IT. Selain itu, intervensi SSG dan IT sama-sama efektif dalam meningkatkan distance covered sesuai dengan peningkatan kinerja dari pretest ke posttest pada YYIR2. SSG dan IT mempunyai pengaruh terhadap daya tahan aerobik, namun memiliki perbedaan dalam bentuk latihan menggunakan bola dan tanpa bola. IT lebih baik digunakan pada periode persiapan umum karena pada periode ini daya tahan aerobik menjadi komponen fisik yang harus ditingkatkan secara maksimal. Sedangkan SSG cocok digunakan pada saat periode persiapan khusus dan periode kompetisi sehingga tingkat daya tahan aerobik pemain dapat terjaga dan pada saat yang bersamaan tetap bisa meningkatkan skill teknik dengan bola.

Akhirnya, pelatih tim sepakbola U-17 harus memvariasikan aturan dan format SSG untuk mendukung komponen taktis, teknis, atau fisik, atau semuanya, tidak hanya sesuai dengan tujuan pelatihan dan periode musim (Hill-Haas et al, 2011; Koklu et al., 2013) tetapi juga berdasar pada tingkat tim yang membedakan pemain muda, amatir, dan pemain profesional dan elit (Dellal et al., 2011; Hill-Haas et al, 2011).

\section{SIMPULAN}

Berdasarkan hasil penelitian dan analisis data yang telah dilakukan dapat ditarik kesimpulan bahwa tidak ada perbedaan pengaruh yang signifikan antara SSG dan IT terhadap peningkatan daya tahan aerobik pemain sepakbola U-17. SSG dan IT mempunyai pengaruh terhadap daya tahan aerobik, namun memiliki perbedaan dalam bentuk latihan menggunakan bola dan tanpa bola. SSG dan IT mempunyai karakteristik masingmasing. Pelatih dapat memilih metode latihan sesuai dengan kebutuhan dan situasi di lapangan disesuaikan dengan kapasitas aerobik dan waktu yang dimiliki. Program latihan yang dibuat harus sesuai dengan periodesasi latihan sehingga daya tahan aerobik dapat meningkat secara maksimal.

\section{DAFTAR PUSTAKA}

Badin, O. O., Smith, M. R., Conte, D., \& Coutts, A. J. (2016). Mental fatigue: Impairment of technical performance in small-sided soccer games. International Journal of Sports Physiology and Performance, 11(8), 1100-1105. https://doi.org/10.1123/ijspp.2015-0710

Beato, M., Bertinato, L., \& Schena, F. (2014). High volume training with small-sided games affects technical demands in football: a descriptive study. Sport Sciences for Health, 10(3), 219-223. https://doi.org/10.1007/s11332-014-01976

Bompa, T. O., \& Haff, G. (2009). Periodization: 


\section{Jurnal Keolahragaan 7 (2), 2019 - 189}

Andi Tri Arianto, Caly Setyawan

Theory and methodology of training. Human Kinetics.

Casamichana, D., Román-Quintana, J. S., Castellano, J., \& Calleja-González, J. (2015). Influence of the type of marking and the number of players on physiological and physical demands during sided games in soccer. Journal of Human Kinetics, $47(1)$, 259-268. https://doi.org/10.1515/hukin-2015-0081

Christopher, J., Beato, M., \& Hulton, A. T. (2016). Manipulation of exercise to rest ratio within set duration on physical and technical outcomes during small-sided games in elite youth soccer players. Human Movement Science, 48, 1-6. https://doi.org/10.1016/j.humov.2016.03.0 13

Clemente, F. M., Martins, F. M. L., \& Mendes, R. S. (2014a). Developing aerobic and anaerobic fitness using small-sided soccer games: Methodological proposals. Strength and Conditioning Journal, 36(3), 76-87.

https://doi.org/10.1519/SSC.00000000000 00063

Clemente, F. M., Martins, F. M. L., \& Mendes, R. S. (2014b). Periodization based on small-sided soccer games. Strength and Conditioning Journal, 36(5), 34-43. https://doi.org/10.1519/SSC.00000000000 00067

Danurwindo, D., Putera, G., Sidik, B., \& Prahara, J. L. (2017). Kurikulum pembinaan sepakbola Indonesia. High Performance Unit Football Association of Indonesia.

Dellal, A., Varliette, C., Owen, A., Chirico, E. N., \& Pialoux, V. (2012). Small-sided games versus interval training in amateur soccer players: Effects on the aerobic capacity and the ability to perform intermittent exercises with changes of direction. Journal of Strength and Conditioning Research, 26(10), 2712-2720. https://doi.org/10.1519/JSC.0b013e31824 $294 \mathrm{c} 4$

Deol, N. S., \& Singh, J. (2013). Effect of continuous running and interval training methods on endurance ability of football players. International Journal of Behavioral Social and Movement Sciences, 2(1), 333-339.

Foster, C., Farl, C. V., Guidotti, F., Harbin, M.,
Roberts, B., Schuette, J., Tuuri, A., Doberstein, S. T., \& Porcari, J. P. (2015). The effects of high intensity interval training vs steady state training on aerobic and anaerobic capacity. Journal of Sports Science and Medicine, 14(4), 747-755.

Halouani, J., Chtourou, H., Dellal, A., Chaouachi, A., \& Chamari, K. (2017). Soccer small-sided games in young players: rule modification to induce higher physiological responses. Biology of Sport, 2(2), 163-168. https://doi.org/10.5114/biolsport.2017.645 90

Helgerud, J., Engen, L. C., Wisløff, U., \& Hoff, J. (2001). Aerobic endurance training improves soccer performance. Medicine and Science in Sports and Exercise, $33(11)$, 1925-1931. https://doi.org/10.1097/00005768200111000-00019

Hill-Haas, S. V., Coutts, A. J., Rowsell, G. J., \& Dawson, B. T. (2009). Generic versus small-sided game training in soccer. International Journal of Sports Medicine, 30(09), 636-642. https://doi.org/10.1055/s-0029-1220730

Hill-Haas, S. V., Dawson, B., Impellizzeri, F. M., \& Coutts, A. J. (2011). Physiology of small-sided games training in football. Sports Medicine, 41(3), 199-220. https://doi.org/10.2165/11539740000000000-00000

Hoff, J., Wisløff, U., Engen, L. C., Kemi, O. J., \& Helgerud, J. (2002). Soccer specific aerobic endurance training. British Journal of Sports Medicine, 36(3), 218-221. https://doi.org/10.1136/bjsm.36.3.218

Impellizzeri, F., Marcora, S., Castagna, C., Reilly, T., Sassi, A., Iaia, F., \& Rampinini, E. (2006). Physiological and performance effects of generic versus specific aerobic training in soccer players. International Journal of Sports Medicine, 27(6), 483492. https://doi.org/10.1055/s-2005865839

Italo, S., \& Cofano, G. (2017). Small-sided games in young soccer players: Physical and technical variables. MOJ Sports Medicine, 1(1), 4-7. https://doi.org/10.15406/mojsm.2017.01.0 0001

Joo, C. H., Hwang-Bo, K., \& Jee, H. (2016). 


\section{Jurnal Keolahragaan 7 (2), 2019 - 190}

Andi Tri Arianto, Caly Setyawan

Technical and physical activities of smallsided games in young Korean soccer players. Journal of Strength and Conditioning Research, 30(8), 2164-2173. https://doi.org/10.1519/JSC.00000000000 01319

Katis, A., \& Kellis, E. (2009). Effects of smallsided games on physical conditioning and performance in young soccer players. Journal of Sports Science and Medicine, 8(3), 374-380.

Köklü, Y., Albayrak, M., Keysan, H., Alemdaroğlu, U., \& Dellal, A. (2013). Improvement of the physical conditioning of young soccer players by playing smallsided games on different pitch size special reference to physiological responses. Kinesiology, 45(1), 41-47. https://hrcak.srce.hr/104546

Krustrup, P., Mohr, M., Amstrup, T., Rysgaard, T., Johansen, J., Steensberg, A., Pedersen, P. K., \& Bangsbo, J. (2003). The Yo-Yo intermittent recovery test: Physiological response, reliability, and validity. Medicine \& Science in Sports \& Exercise, 35(4), 697-705. https://doi.org/10.1249/01.MSS.00000584 41.94520 .32

Lacome, M., Simpson, B. M., Cholley, Y., Lambert, P., \& Buchheit, M. (2018). Small-sided games in elite soccer: Does one size fit all? International Journal of Sports Physiology and Performance, 13(5), 568-576. https://doi.org/10.1123/ijspp.2017-0214

Los Arcos, A., Vázquez, J. S., Martín, J., Lerga, J., Sánchez, F., Villagra, F., \& Zulueta, J. J. (2015). Effects of small-sided games vs. Interval training in aerobic fitness and physical enjoyment in young elite soccer players. PLOS ONE, 1O(9), e0137224. https://doi.org/10.1371/journal.pone.0137 224

Macpherson, T. W., \& Weston, M. (2015). The effect of low-volume sprint interval training on the development and subsequent maintenance of aerobic fitness in soccer players. International Journal of Sports Physiology and Performance, 10(3), 332-338. https://doi.org/10.1123/ijspp.2014-0075

Mara, J. K., Thompson, K. G., \& Pumpa, K. L. (2016). Physical and physiological characteristics of various-sided games in elite women's soccer. International Journal of Sports Physiology and Performance, 11(7), 953-958. https://doi.org/10.1123/IJSPP.2015-0087

O’Reilly, R. K., Gibson, V. C., White, A. J. P., \& Williams, D. J. (2004). Five-coordinate iron(II) complexes bearing tridentate nitrogen donor ligands as catalysts for atom transfer radical polymerisation. Polyhedron, 23(17), 2921-2928. https://doi.org/10.1016/j.poly.2004.09.001

Pandey, S. K., \& Verma, S. (2016). Effect of interval training method and repetition training method on the performance of 200 meters sprint. International Journal of Physical Education, Sports and Health, 3(2),

133-135. http://www.kheljournal.com/archives/201 6/vol3issue2/PartC/3-2-17.pdf

Pattyn, N., Beckers, P. J., Cornelissen, V. A., Coeckelberghs, E., De Maeyer, C., Frederix, G., Goetschalckx, K., Possemiers, N., Schepers, D., Van Craenenbroeck, E. M., Wuyts, K., Conraads, V. M., \& Vanhees, L. (2017). The effect of aerobic interval training and continuous training on exercise capacity and its determinants. Acta Cardiologica, 72(3), 328-340. https://doi.org/10.1080/00015385.2017.13 04712

Reilly, T., \& Gilbourne, D. (2003). Science and football: a review of applied research in the football codes. Journal of Sports Sciences, 2l(9), 693-705. https://doi.org/10.1080/026404103100010 2105

Sangnier, S., Cotte, T., Brachet, O., Coquart, J., \& Tourny, C. (2019). Planning training workload in football using small-sided games' density. Journal of Strength and Conditioning Research, 33(10), 28012811.

https://doi.org/10.1519/JSC.00000000000 02598

Sarmento, H., Clemente, F. M., Harper, L. D., Costa, I. T. da, Owen, A., \& Figueiredo, A. J. (2018). Small sided games in soccer - a systematic review. International Journal of Performance Analysis in Sport, 18(5), 693-749.

https://doi.org/10.1080/24748668.2018.15 


\section{Jurnal Keolahragaan 7 (2), 2019 - 191}

Andi Tri Arianto, Caly Setyawan

\section{8}

Serra-Olivares, J., González-Víllora, S., GarcíaLópez, L. M., \& Araújo, D. (2015). Gamebased approaches' pedagogical principles: Exploring task constraints in youth soccer. Journal of Human Kinetics, 46(1), 251261. https://doi.org/10.1515/hukin-20150053

Thomas, A., Dawson, B., \& Goodman, C. (2006). The yo-yo test: Reliability and association with a 20-m shuttle run and VO2max. International Journal of Sports Physiology and Performance, 1(2), 137-149. https://doi.org/10.1123/ijspp.1.2.137

Turner, A. N., \& Stewart, P. F. (2014). Strength and conditioning for soccer players. Strength and Conditioning Journal, 36(4), $1-13$.
https://doi.org/10.1519/SSC.00000000000 00054

Turnes, T., de Aguiar, R. A., Cruz, R. S. de O., \& Caputo, F. (2016). Interval training in the boundaries of severe domain: effects on aerobic parameters. European Journal of Applied Physiology, 116(1), 161-169. https://doi.org/10.1007/s00421-015-32630

Vilar, L., Duarte, R., Silva, P., Chow, J. Y. i., \& Davids, K. (2014). The influence of pitch dimensions on performance during smallsided and conditioned soccer games. Journal of Sports Sciences, 32(19), 17511759.

https://doi.org/10.1080/02640414.2014.91 8640 